\title{
Bakunin and the Jura Federation
}

\author{
Marianne Enckell \\ Translated from the French by Constance Bantman
}

In the autumn of 2014, a commemorative plaque was put up in Le Locle, a small town in the Neuchâtel district (Switzerland), on the wall of the Café de la poste, as an homage to Michael Bakunin, who had given a talk there in February 1869. Contrary to what is stated on the plaque, of course, he did not give "a conference on anarchism": ${ }^{1}$ while the word "anarchism" or "anarchy" was indeed present in political philosophy, nothing at the time heralded the anarchist movement or a coherent theory.

Upon his return to Geneva, he wrote to the Le Locle comrades: “Isn't it a wonderful thing that a man, a Russian, an ex-nobleman, who until very recently was a complete stranger to you, and who has set foot in your country for the first time, should find himself surrounded by hundreds of brothers?"

And indeed, the meeting, James Guillaume recalled, ${ }^{3}$ had been a "familiar evening; consequently, after an hour dedicated to philosophy and socialism, there was dancing in the very room where the conference had been given, after the benches and chairs had been removed, while Bakunin, who had withdrawn to a neighbouring room, chatted with a few mature men who favoured talking to him over the noisy pleasures of youth."

There was dancing? The International sections' members were without doubt almost all male; but women attended conferences and informal evenings: "The way the International's speakers were greeted went beyond the wildest hopes of the event's promoters. We heard a woman say on her way out: - Ha, if only I were a man I wouldn't lose any time in getting into the International! - But, shall we say in reply, there is no need to be a man in order to be

1 In his introduction to the first volume of Bakunin's CEuvres (Paris, 1895), Max Nettlau wrote: "Bakunin went - for the first time - to the Jura where, on 21 February 1869, at the cercle international of Le Locle, he gave a conference on 'The people's philosophy'. This conference fell into two parts, one of which dealt with 'the religious question', while the other was devoted to 'the history of the bourgeoisie, its development, its rise and its fall'". The six volumes of the CEuvres published from 1895 to 1913 are available in French online on Wikisource. Unless otherwise stated, all translations are the translator's own.

2 Le Progrès, organe des démocrates loclois, n. 6, 1st March 1869.

3 James Guillaume, L'Internationale, 2 vol. (Paris 1905), vol. 1, p. 130.

(C) MARIANNE ENCKELL, 2018 | DOI 10.1163/9789004335462_024

This is an open access chapter distributed under the terms of the prevailing CC-BY-NC License. 
part of the International; women workers suffer from the oppression of capital just as much as men do, and consequently they are just as entitled as men to join the great Workingmen's Association."4 Only in Geneva did a short-lived "section des Dames" (Ladies' section) come into existence, despite a few efforts to the same end elsewhere in French-speaking Switzerland. ${ }^{5}$

Another major reason why the International took hold so quickly in the Neuchâtel Mountains and the Saint-Imier valley, is that the local populations were familiar with organisations mixing ideal goals and forms of sociability. ${ }^{6}$ The International Working men's Association (IWMA) sections created there since 1865 were "multi-coloured groupings", 7 and remained so in the following years: mutual help societies, trade unions, craft unions, associations, propaganda or working-class culture clubs and societies. The statutes letter, the contents of the Inaugural Address remained for most of them temporary texts, or even abstract texts, which had to be tested in reality.

Facts - rather than theories. But Bakunin gave them food for thought: after his talk, he sent a series of articles to the local journal Le Progrès, in the form of long letters Aux compagnons de l'Association Internationale des Travailleurs du Locle et de la Chaux-de-Fonds (To the comrades of the IWMA in the Locle and La Chaux de Fonds), where he traced the evolution of the bourgeoisie and then liberalism, and criticised the state and patriotism. A second series appeared under the title Lettres sur le patriotisme (Letters on patriotism), ${ }^{8}$ still with the tone of a discussion between friends, still unfinished, like most of Bakunin's writings.

Bakunin, at the time, was enthusiastic about the International. The previous year, he had tried to talk the Ligue de la paix et de la liberté (Peace and Freedom League) into subscribing to it, or even merging with it; but the Ligue had refused to embark on the path of social change. ${ }^{9}$ Soon after he left the Ligue with a handful of faithful friends, he launched with them the project of

4 La Solidarité, 11 June 1870.

5 See Antje Schrupp, "Die Genfer Frauensektion der Ersten Internationale", http://www .antjeschrupp.de/die-genfer-frauensektion, last accessed 4 May 2015.

6 See Hans Ulrich Jost, "Sociabilité, faits associatifs et vie politique en Suisse au XIX ${ }^{\mathrm{e}}$ siècle", in A tire d'ailes (Lausanne, 2005), pp. 117-143.

7 Miklós Molnar, Le déclin de la Première Internationale: la conférence de Londres de 1871 (Geneva, 1963), p. 34.

8 Le Progrès, February to May 1869 , then June to October; articles reproduced in Bakunin, OEuvres, vol. 1.

9 Bulletin sténographique du deuxième Congrès de la paix et de la liberté (Bern, 22-25 September 1868). See also a letter from Elisée Reclus to his brother Elie, Correspondance, 3 vol. (Paris, 1911), vol. 1, p. $279 \mathrm{ff}$. 
an Alliance Internationale de la Démocratie socialiste (International Alliance of socialist Democracy), which was set up in Geneva on 28 October. ${ }^{10}$ The Alliance, claiming to bring dynamism to the IWMA, make it progress theoretically and practically and go ahead with propaganda, soon reorganised into regional sections, in order to be accepted by the IWMA's General Council, and into a secret brotherhood, a force for reflection and organisation. It was one of the secret organisations which Bakunin liked to launch under various names, so that their genealogy could not be established.

But, as he left the Ligue for the Geneva section of the IWMA, he noted among other things that "the founders of the IWMA acted with great wisdom by first removing from the organisation's agenda all political and religious questions. There is no doubt that they themselves were not short of resolute political opinions, nor of antireligious opinions; but they refrained from enshrining them in this programme, because their main goal was above all to unite into a common action the labouring masses the civilised world over".11

The series of articles published in Le Progrès provides a remarkable summary of his political theories in their contemporary context. In a few brief extracts:

Until 1848, [the bourgeoisie] was still highly spirited. Without a doubt $[\ldots]$ it no longer was the heroic spirit of a class which had once been full of daring because it had been forced to conquer everything; it was the wise and thoughtful spirit of a new owner who, after acquiring a muchcoveted good, must now make it prosper and increase in value.

Exploitation is the visible body, and government is the soul of the bourgeois regime. [...] Both of these, in this highly intimate relation, are from a theoretical as well as a practical viewpoint, the necessary and faithful expression of metaphysical idealism, the unavoidable consequence of this bourgeois doctrine which seeks individual freedom and morality outside social solidarity.

[But the state is] the immolation of each individual as well as all local associations, the destructive abstraction of living society, the limitation or, in better words, the complete negation of life [...] The state has all always been the heirloom of a given privileged class: the sacerdotal class, the nobiliary class, the bourgeois class; - the bureaucratic class at the end.

10 A copy of the invitation, which includes the statutes and rules and carries 10 signatures, can be found in the Biblioteca Franco Serantini in Pisa; others are at Amsterdam's International Institute of Social History.

11 "Politique de l'Internationale", L'Egalité, Geneva, August 1869; articles reprinted in CEuvres, (Stock, 1911) vol. 5, p. $172 \mathrm{ff}$. 
Patriotism is a bad, narrow and grim habit, since it denies human equality and solidarity. The social question which, nowadays, is being raised in practical terms by Europe's and America's working classes, and whose solution is only possible if state borders are abolished, tends necessarily to destroy this traditional habit in the consciousness of workers of all countries.

Only socialism, by replacing political, judicial and godly justice with human justice, by replacing patriotism with the universal solidarity of men, and economic competition with the international organisation of a society entirely founded on work, can put an end to all these brutal manifestations of human animality, to war.

\section{Disagreements in Switzerland}

The first IWMA sections in Switzerland had toyed with parliamentary politics, and frequently sided with the radical party which was keen to court workers, in Geneva where it was in the opposition, as well as in Le Locle. Others, like doctor Coullery, sought alliances with the conservative opposition. ${ }^{12}$ In the wake of electoral defeats, the members of the International in the Jura easily came to the conclusion that this type of politics was useless; it is hardly surprising that they welcomed Bakunin's words to them.

In Fédéralisme, socialisme et antithéologisme ${ }^{13}$ he had set out the programme which he presented to the Ligue de la Paix et de la Liberté in 1867; it was after this was rejected that Bakunin moved for good to the IWMA's side. It was in this programme, indeed, that he suggested breaking away from old states once and for all and organising society from the bottom up - "the free federation of individuals into towns, of towns into provinces, of provinces into nations and finally of the latter into the United States of Europe first and then, later, of the entire world".

Between the Swiss Jura watchmakers and Bakunin, there was therefore an encounter, and complementary experiences. Bakunin came back to the area, for other conferences in Le Locle, and for other, longer stays between Sonvilier and Saint-Imier. Two years later, he told them: "By working in small groups in

12 See Marc Vuillemier, "La Première Internationale en Suisse", La Première Internationale (Paris, 1968). The radicals and the catholic conservatives were the main two political currents in Switzerland at the time; they became national parties after the 1874 Federal Constitution was adopted in 1874 .

13 Written around 1867. Reprinted in CEuvres, vol. 1. 
your workshops, and even by working in your own place, you earn much more money than can be earned in the large industrial establishments employing hundreds of workers; your work is intelligent, artistic, it does not deaden the mind in the same way that machine work does. Your skill, your intelligence count for something. Moreover you have far more leisure and relative freedom; this is why you are more educated, freer and happier than the others."14

Freer, no doubt, since the break within the IWMA's French-speaking Federation which had brought together Switzerland's French-language sections since 1869; the International never really took root in Alemannic Switzerland. In April 1870 a split occurred between the Geneva sections, which opposed political abstention, and the sections located in the Neuchâtel Mountains, which insisted on "giving up any action aiming to effect social transformation through national political reform". ${ }^{15}$ A year and a half later, the latter renamed themselves the Jura Federation - at the risk of not being recognised by London's General Council, which required that there be only one federation per country.

It is beyond doubt that Bakunin and his friends' manoeuvres played a role in this process, but it is hard to know precisely what role. Much later, when Max Nettlau carried on indefatigably his research into Bakunin's life and writings and enquired to him about secret societies, James Guillaume wrote to him:16 "After carefully weighing the pros and cons, I decided, for good, to observe complete silence regarding the Brotherhood and everything deriving from it. One should be able to tell everything: but, on one hand, we don't know everything; on the other hand, certain things still cannot be told." In the first volume of L'Internationale, documents et souvenirs, published in 1905, he gave a little more away: "It was not an association after the classical type of the old secret societies, in which one was expected to follow orders from on high: the organisation was nothing else than the free gathering of men united towards collective action, without forms, without solemnity, without mysterious rites, just because they trusted one another and it seemed to them that an alliance was preferable to isolated action."17 A century of commentaries and interpretations, from Marx to Arthur Lehning, ${ }^{18}$ has not made it possible for historians to draw definite conclusions; I will not take the chance.

\footnotetext{
14 "Trois conférences aux ouvriers du val de Saint Imier" [May 1871], in OEuvres, vol. 5, p. 325.

15 La Solidarité, Neuchâtel, 11 April 1870.

16 Letter dated 30 July 1904, in Max Nettlau, Nachträge, note 44296+, available online on the website of Amsterdam's IISG, https://search.socialhistory.org/Record/ARCHo1oo1, Content list (n. 1698), accessed February 28, 2015.

17 Guillaume, L'Internationale, p. 131.

18 Karl Marx, L'Alliance de la democratie socialiste et l'Association internationale des travailleurs (London, 1873). Arthur Lehning, “Bakunin's Conceptions of Revolutionary
} 
For the "Jurassians", the International was "not only this formal organisation which, nowadays, embraces part of the proletariat: organisations are a secondary and transitory thing; they develop, transform and sometimes tear away like an item of clothing which is too small."19 The International was a perfectible, but truly legitimate form for organising the proletariat; the more universal it became, the more it would have to accommodate diversity in its midst. The conflict between Marx's champions and Bakunin's, between "centralists" and "federalists", therefore had as much to do with its social project (the emancipation of the proletariat through the conquest of political power for the former, through the abolition of any political power for the latter) as with the organisation of the International; for the Federalists, the General Council could not be a governing body but should restrict itself to being a mere coordinating organ, a correspondence bureau between autonomous regional sections.

\section{The Saint-Imier Congress}

Both elements - the social project and organisational matters - provided direction to the Saint-Imier "anti-authoritarian" congress on Sunday 15 September 1872. A week earlier, the majority of the Hague congress had excluded Bakunin - in his absence - and James Guillaume from the IWMA; the minority group accepted the proposal put forward by the Italian Federation (which was not represented at the Hague), to hold an international congress in Switzerland.

Fifteen delegates presented their mandates. Four of them came from Spain a typographer, a barber and an engraver, as well as a French teacher. Five came from Italy, including three young men as well as the Russian Bakunin and his old friend Fanelli, who had spread his ideas in Spain. Two Frenchmen based in Switzerland represented "several French sections" existing clandestinely. Two American sections delegated a French communard refugee living in Switzerland. Finally, two Swiss, an engraver and a printer, represented the Jura Federation.

For the most part these were young men: they were between 20 and 30, except for their elder Bakunin, who was born in 1814, and two 45 year old men, Giuseppe Fanelli and Gustave Lefrançais. They had been active members of IWMA sections for five or six years, or even a lot less. Some of them had already been sent as representatives to international congresses, and several were back

Organisations and Their Role. A Study of his 'Secret Societies", in Essays in honour of E.H. Carr (London, Basingstoke, 1974), pp. 57-81.

19 James Guillaume, "Le 18 mars", Bulletin de la Fédération jurassienne, 4, 20 March 1872. 
from the Hague conference. Others had travelled via Zurich in order to confer with Bakunin first.

The international delegates arrived in Saint-Imier from Bienne or La Chauxde-Fonds, by stage-coach, cart or even by foot: the train did not travel there yet, it was built two years later. At that time the town counted 4 to 5,00o inhabitants, as many as today. It underwent a large-scale alignment plan after the serious mid-century fires; the streets were rebuilt and working-class dwellings of four or five floors were erected. ${ }^{20}$

The Maison-de-Ville (Central hotel) where the congress took place was probably smart: it was built after the last great fire of 1856 . It was the usual calling point of établisseurs - the skilled masters of the watchmaking industry and trade - coming to collect the spare pieces made in the local villages in order to assemble watches in factories. Watchmaking, which had developed there for about 40 years, had drawn many new dwellers from Alemannic Switzerland, the Jura and neighbouring France. It was mainly practiced in small workshops or at home, but the Longines factory (named after the place where it was built) opened there in 1867 and played a role in further transforming the urban and industrial landscape. ${ }^{21}$

The congress was held in three languages - French, Italian and Spanish, with three presidents and three secretaries (a Swiss engraver was chosen outside the delegates' circle). In accounts, newspaper articles, contemporary correspondence, no one seems to be surprised or intimidated by this, nor to have found it difficult. The delegates, as discussed above, hailed from countries where one Latin language or another was spoken; this did not change when the Belgian Federation's joined, later. Moreover, James Guillaume spoke English fluently and Adhémar Schwitzguébel spoke German; later on, they translated correspondences or congress talks.

This shows that the International had become a motherland - "Nostra patria è il mondo intero", as the Italian anarchists expelled from Switzerland were to sing 20 years later.

The questions on the agenda were tangible, intended for immediate application. Four resolutions were adopted: the first one reasserted the principles

\footnotetext{
20 I wish to thank Catherine Krüttli, from the archival centre Mémoires d'ici (m-ici.ch) for providing me with a file on the history of local urbanism.

21 See, among others, Robert Pinot, Paysans et horlogers jurassiens (Geneva, [1887] 1979); Patrick Linder, De l'atelier à l'usine: l'horlogerie à Saint-Imier (Neuchâtel, 2008). Regarding the watchmaking process: Jean-Frederic Gerber, "Le syndicalisme ouvrier dans l'industrie suisse de la montre de 1880 à 1915", in Erich Gruner et al., Arbeiterschaft und Wirtschaft in der Schweiz, 1880-1914, 3 vol. (Zurich, 1988) vol. 2, pp. 279-290.
} 
of autonomy and federalism, "the first condition for workers' emancipation"; the second drew "a friendship, solidarity and mutual defence pledge" between the organisations which were represented; the third proudly declared, in direct response to the General Council's injunctions, "that the destruction of any political power is the proletariat's first duty"; the fourth reflected upon the ways "of strengthening workers' organisation and, through simple economic battles, preparing the Proletariat for the great and definitive revolutionary struggle which, destroying all privileges and all class distinctions, would give workers the right to enjoy the entire product of their labour". ${ }^{22}$

Aside perhaps from the third resolution, this was therefore not an anarchist programme, but a set of principles aiming to rebuild the International whilst respecting regional differences.

For several years, the Jura federal committee would act as a correspondence bureau between "anti-authoritarian" federations. From its very beginnings, the weekly Bulletin de la Fédération jurassienne (1872-78) published letters from abroad, translated the main congress resolutions, kept the discussion going. Subscriptions from the whole world were registered with Sonvilier-based engraver Adhémar Schwitzguébel. The Bulletin had a few dozen international subscribers: ${ }^{23}$ in Alsace, Belgium, Spain and Italy for instance, regularly paying 5 francs a year. In 1877 , about 50 copies were sent free of charge, for propaganda purposes, to cafés in the area and newspapers from Le Locle, La Chaux-deFonds, Geneva, Neuchâtel, Porrentruy, Zurich; to anarchist or socialist papers in Verviers, Antwerp, Berlin, Leipzig, Hamburg, Amsterdam, the Hague, Barcelona, Mexico City, Milan, Sienna, Rimini, to Alexandria in Egypt; to comrades in Patras, Greece, to Lisbon, Madrid, Montevideo, London, to Iowa or Italy's Capua Vetere prison, where Errico Malatesta was a prisoner, but also to professor Eugen Dühring at Berlin University.

\section{The Cradle of Anarchism}

Simultaneously and concurrently, the notion of an anarchist movement was taking shape. The word had gained great currency among its champions as well as its detractors, and utopia was among the goals of several groups.

In September 1871, the International's Spanish regional Federation declared that "the real federal democratic republic means collective ownership, Anarchy

\footnotetext{
22 Bulletin de la Fédération jurassienne, 17-18, 15 September 1872 (in fact, October 1st).

23 List of the subscribers to the Bulletin, IISH, Amsterdam, Fédération jurassienne Archives, file 116 .
} 
and economic federation, that is to say the free and universal federation of free associations of agricultural and industrial workers" 24 - a federation which was intended as a negation of the state, political parties and constituent assemblies, and as a statement of the spontaneous and revolutionary organisation of freely-federated communes and autonomous groups.

In spring 1873 , it was the Italians who claimed that "anarchy, for us, is the only way for social Revolution to be a fact, for social liquidation to be complete ... for passions and natural needs, returning to their state of freedom, to carry out the reorganisation of mankind on grounds of justice."25

In contrast, other comrades such as Benoît Malon, claimed that the "anarchist programme" was an impossibility. James Guillaume opposed it too, but for other reasons: he used "anarchy" in Proudhon's sense, he accepted "anarchist" as an adjective but found these terms negative and equivocal. ${ }^{26}$ The federations from Belgium and the Netherlands concurred with him.

As for Bakunin, he chose that time to withdraw, at least formally. He wrote a public letter to the Journal de Genève, and then a text to his Jura friends: ${ }^{27}$ "Now is no longer the time for ideas, but for facts and actions. What matters above all, today, is to organise proletarian forces. But such organisation must be carried out by the proletariat itself. If I was young, I would have transported myself to a working class environment and, sharing my brothers' industrious life, I would also have taken part with them in the great labour of this necessary organisation." Personal conflicts also surfaced, and the break-up was painful. But this shows clearly that it was not Bakunin who "invented" the Jura militants' anarchism, as the latter carried on without him.

On 3 March 1877, Elisée Reclus gave a conference in Saint-Imier about anarchy and the state: "After reducing bourgeois fanciful frights in the face of the word 'anarchy' to their actual worth," the Bulletin summarised, "he explained the word's scientific meaning, and how we should focus on it. He reviewed the state's various forms - the theocratic, royal, aristocratic and lastly the popular state -, and demonstrated how the latter, aiming for people to be governed by

24 Quoted by Mathieu Léonard, L'Emancipation des travailleurs (Paris, 2011), p. 293.

25 Bulletin de la Fédération jurassienne, 1st April 1873.

26 He also wrote, in 1876, in the Bulletin: "No such thing as an 'anarchist programme' has ever been formulated, as far as we know ... But there is a collectivist theory, articulated in the congresses of the International, and that's the one we associate with, as do our friends from Belgium, France, Spain, Italy and Russia". He was always careful to write the word anarchist in italics.

27 Journal de Genève, 25 September 1873; Bulletin de la Fédération jurassienne, 12 October 1873 . 
the people, when truly implemented, resulted logically in anarchy ... this horizon of freedom which we want for human society". ${ }^{28}$

Within 5 years - from September 1872 to the summer of 1877 - the anarchist movement acquired its own life and identity. Referring to movements or militants as anarchists prior to that date is anachronistic.

The IWmA Congress in The Hague, in 1872, had allowed the General Council to save face, but at the cost of losing almost all the affiliated federations. It may be asked whether, subsequently, one of the Association's two strands was more powerful than the other. The "centralist" branch was near-defunct; its 1873 Geneva congress was a flop. As for the "federalist" branch, it survived for another 5 years; it was not a Bakuninist fraction nor an anarchist cell, but a "genuinely proletarian and internationalist movement," as described by Miklós Molnar. ${ }^{29}$ In Geneva in September 1873, just before the "centralist" congress, it brought together section and federation delegates, often with substantial memberships, from 7 countries: England, Belgium, Spain, France, Holland, Italy, "Jura". ${ }^{30}$ English sections were still present in 1874 at its Brussels congress, when the IWMA no longer had any public presence in France: several sections federated from 1876, in France or even in exile.

The last (federalist) congress of the IWMA took place in 1877 in Verviers, in Belgium. It brought together delegates from France, Italy, Spain, Germany, Russia, Switzerland and Belgium, ${ }^{31}$ and received correspondences from Greece, Egypt and Uruguay. The discussions focused on solidarity, internationalism; manifestoes of support were sent to "those among our brothers who have been victims of their revolutionary energy" in Russia, in Italy, in Switzerland or in the United States. ${ }^{32}$ There were discussions about collectivism and communism, political parties and revolutionary socialism. Nothing there was terribly original, except that the delegates sought to overcome their differences and give an added lease of life to their association. But this was not meant to be.

The following year, the Jura Federation gave up. In its own congresses it explored in greater depth the issues of autonomy, federalism and internationalism. Its swan song was - rather paradoxically - a programmatic text: that which the Saint-Imier region Federation put up for discussion at the 1880

28 Bulletin de la Fédération jurassienne, 11 March 1877.

29 "Quelques remarques à propos de la crise de l'Internationale en 1872 ", La Première Internationale (Paris, 1968).

30 The minutes of this congress and the following ones are reprinted in Jacques Freymond (ed.), La Première Internationale, recueil de documents, 4 vol. (Geneva, 1962-1971) vol. 4.

$3^{1} \quad I d .$, p. $5^{23}$.

$32 \quad I d .$, p. 530. 
congress, through the voice of its secretary Adhémar Schwitzguébel. ${ }^{33}$ Stressing, among other things, the need for organisation "from the point of view of preparatory action for the revolution and revolutionary action itself," he specified that "trade organisations, study and propaganda groups, local, regional and international workers' federations, socialist and revolutionary conspiracies are as many varied forms giving satisfaction to the organisational needs of the different economic, political and social environments. In terms of organisation, therefore, there is no such thing as an absolute form: they all have their raison d'être according to the specific situations and goals through which they work towards the realisation of the general goal".

That's what it means - this fine word "International". It all began in Switzerland, thanks too to the presence of foreigners and political refugees there: a situation which, unfortunately, has changed a lot over time, and not only with respect to anarchists.

33 Programme socialiste: mémoire présenté au Congrès jurassien de 1880 par la Fédération ouvrière du district de Courtelary (Geneva, 1880), 32 p. 